\title{
Polyphasic assignment of an aromatic- degrading Pseudomonas sp., strain DJ77, in the genus Sphingomonas as Sphingomonas chungbukensis sp. nov.
}

\author{
Seong-Jae Kim, ${ }^{1}$ Jongsik Chun, ${ }^{2}$ Kyung Sook Bae ${ }^{2}$ \\ and Young-Chang Kim ${ }^{1}$
}

1 School of Life Sciences, Chungbuk National University, Cheongju, 360763 , Republic of Korea

2 Korean Collection for Type Cultures, Korea Research Institute of Bioscience \& Biotechnology, PO Box 115, Yusong, Taejon 305-600, Republic of Korea

\author{
Author for correspondence: Young-Chang Kim. Tel: +82 431261 2302. Fax: +824312682538. \\ e-mail: youngkim@cbucc.chungbuk.ac.kr
}

\begin{abstract}
Pseudomonas sp. strain DJ77, which was described as an aromatic-degrading bacterium, was investigated to clarify its taxonomic position. Phylogenetic analysis based on 16S rDNA sequences indicated that the strain belonged to the genus Sphingomonas and formed a monophyletic clade with the type strains of Sphingomonas chlorophenolica, Sphingomonas herbicidovorans and Sphingomonas yanoikuyae with sequence similarity values of 98.1, 96.1 and $95.6 \%$, respectively. Genomic relatedness based on DNA-DNA hybridization of strain DJ77 to these strains is 7-14\%. Strain DJ77 contained ubiquinone 10 as the main respiratory quinone, and the $G+C$ content of DNA was $63 \mathrm{~mol} \%$. The organism contained octadecenoic acid (67\%) as major cellular fatty acid. Strain DJ77 can be readily differentiated from representative members of the genus Sphingomonas using a battery of biochemical tests. On the basis of polyphasic evidence, it is proposed that strain DJ77, previously known as Pseudomonas sp., be reclassified in the genus Sphingomonas as Sphingomonas

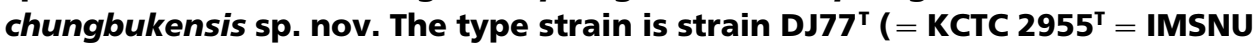
$11152^{\mathrm{T}}$ ).
\end{abstract}

Keywords: Sphingomonas chungbukensis sp. nov., polyphasic classification, 16S rDNA sequencing, DNA-DNA hybridization

\section{INTRODUCTION}

Strain DJ77 ${ }^{\mathrm{T}}$, which degrades biphenyl and phenanthrenes, was isolated from contaminated sediment of an industrial complex near Taejon, Republic of Korea, and subsequently identified as Pseudomonas sp. on the basis of the limited number of morphological and physiologic properties (Kim et al., 1986). Recently, Kim (1999) discovered that the organism was capable of metabolizing a variety of monocyclic aromatic hydrocarbons such as toluene, $m$-xylene, phenol, salicylate, benzoate and $p$-cresol, in addition to polycyclic aromatic compounds. Due to its ability to degrade a broad range of aromatic hydrocarbons, additional studies of metabolic pathways, enzymology and molecular mechanisms have been carried out for

The GenBank accession number for $16 \mathrm{~S}$ rDNA sequence of Sphingomonas chungbukensis DJ77 $\left(=\right.$ KCTC $2955^{\top}=$ IMSNU $\left.11152^{\top}\right)$ is AF159257. this strain (Jung et al., 1996; Kim et al., 1997a, b; Shin et al., 1997; Hwang et al., 1999; Kim et al., 1999). A comparative study showed that the genes and gene orders for aromatic hydrocarbon degradation of strain $\mathrm{DJ} 77^{\mathrm{T}}$ were strikingly similar to the corresponding genes of Sphingomonas species, such as Sphingomonas paucimobilis EPA505, Sphingomonas yanoikuyae B1, 'Sphingomonas agrestis' HV3 and Sphingomonas aromaticivorans F199 (Mueller et al., 1990; Kim, 1996; Yrjälä et al., 1997; Romine et al., 1999). The members of the genus Sphingomonas have been reported to degrade various aromatic hydrocarbons (Wittich et al., 1992; Ka et al., 1994; Fredrickson et al., 1995; Khan et al., 1996). In this study, we applied a polyphasic approach to identify strain $\mathrm{DJ} 77^{\mathrm{T}}$. On the basis of chemotaxonomic, physiological and molecular systematic evidence, we propose that Pseudomonas sp. strain $\mathrm{DJ}^{\mathrm{T}} \mathrm{T}^{\mathrm{T}}$ be reclassified in the genus Sphingomonas as Sphingomonas chungbukensis sp. nov. 
Table 1. Selected physiological characteristics useful for differentiation of strain DJ77 from the type strains of three Sphingomonas species

+ , Positive; w, weakly positive; -, negative.

\begin{tabular}{|c|c|c|c|c|}
\hline Characteristic & $\begin{array}{l}\text { Strain } \\
\text { DJ77 }\end{array}$ & S. chlorophenolica & S. herbicidovorans & S. yanoikuyae \\
\hline \multicolumn{5}{|c|}{ BIOLOG GN MicroPlate system } \\
\hline \multicolumn{5}{|c|}{ Oxidation of: } \\
\hline Dextrin & + & - & $\mathrm{w}$ & + \\
\hline Glycogen & + & - & - & $\mathrm{w}$ \\
\hline Tween 40 & + & - & $\mathrm{w}$ & $\mathrm{w}$ \\
\hline Tween 80 & + & - & - & + \\
\hline$N$-Acetyl-D-glucosamine & - & - & $\mathrm{w}$ & + \\
\hline L-Arabinose & + & - & - & + \\
\hline D-Galactose & - & - & + & + \\
\hline Gentiobiose & - & - & $\mathrm{w}$ & + \\
\hline$\alpha$-D-Glucose & + & + & + & + \\
\hline$\alpha$-Lactose & - & - & - & + \\
\hline Maltose & + & - & $\mathrm{w}$ & + \\
\hline D-Melibiose & - & - & - & + \\
\hline Methyl $\beta$-D-glucoside & - & - & - & + \\
\hline D-Raffinose & - & - & - & + \\
\hline L-Rhamnose & - & - & + & + \\
\hline D-Sorbitol & + & - & $\mathrm{w}$ & - \\
\hline Methylpyruvate & + & + & + & + \\
\hline Acetic acid & - & - & $\mathrm{w}$ & + \\
\hline Formic acid & + & - & - & - \\
\hline D-Gluconic acid & + & - & + & + \\
\hline D-Glucosaminic acid & - & - & + & - \\
\hline$\beta$-Hydroxy-butyric acid & + & + & + & + \\
\hline$\alpha$-Keto-butyric acid & + & - & $\mathrm{w}$ & w \\
\hline DL-Lactic acid & + & - & + & + \\
\hline Quinic acid & - & - & - & + \\
\hline D-Saccharic acid & - & - & - & + \\
\hline Alaninamide & + & - & - & w \\
\hline L-Alanyl-glycine & + & - & - & $\mathrm{W}$ \\
\hline L-Aspartic acid & + & - & - & + \\
\hline L-Glutamic acid & + & - & - & + \\
\hline Glycyl-L-aspartic acid & + & - & - & + \\
\hline L-Proline & + & - & + & + \\
\hline \multicolumn{5}{|l|}{ API 20 NE system } \\
\hline Reduction of nitrate & - & - & - & + \\
\hline Acid from glucose & - & - & - & - \\
\hline Arginine dihydrolase & - & - & - & + \\
\hline Urease & - & - & - & + \\
\hline Hydrolysis of aesculin & - & + & + & + \\
\hline Hydrolysis of gelatin & - & - & - & + \\
\hline pNP- $\beta$-D-galactopyranoside & - & - & - & + \\
\hline \multicolumn{5}{|l|}{ Utilization of: } \\
\hline Glucose & + & + & + & + \\
\hline L-Arabinose & + & - & + & + \\
\hline Mannose & + & - & - & + \\
\hline$N$-Acetyl-glucosamine & - & - & - & + \\
\hline Maltose & + & - & + & + \\
\hline
\end{tabular}


Table 1 (cont.)

\begin{tabular}{|c|c|c|c|c|}
\hline Characteristic & $\begin{array}{l}\text { Strain } \\
\text { DJ77 }\end{array}$ & S. chlorophenolica & S. herbicidovorans & S. yanoikuyae \\
\hline Potasium gluconate & + & - & + & + \\
\hline Caprate & - & - & - & + \\
\hline Malate & - & $\mathrm{W}$ & + & + \\
\hline Citrate & - & - & - & + \\
\hline $\begin{array}{l}\text { Tetramethyl- } p \text {-phenylene } \\
\text { diamine }\end{array}$ & + & + & + & - \\
\hline \multicolumn{5}{|l|}{ API 50 CHB system } \\
\hline \multicolumn{5}{|l|}{ Utilization of: } \\
\hline Glycerol & - & - & - & + \\
\hline D-Arabinose & - & - & - & + \\
\hline D-Xylose & + & - & + & + \\
\hline Galactose & + & - & + & + \\
\hline D-Fructose & + & - & - & + \\
\hline L-Sorbose & - & - & - & + \\
\hline Rhamnose & - & - & - & + \\
\hline Methyl $\alpha$-D-mannoside & - & - & - & + \\
\hline Methyl $\alpha$-D-glucoside & - & - & - & + \\
\hline Amygdalin & - & + & - & + \\
\hline Arbutin & - & - & - & + \\
\hline Aesculin & + & + & + & + \\
\hline Salicin & - & - & - & + \\
\hline Cellobiose & - & + & - & + \\
\hline Lactose & - & - & - & + \\
\hline Melibiose & - & - & - & + \\
\hline Saccharose & - & - & - & + \\
\hline Trehalose & - & - & - & + \\
\hline Melezitose & - & - & - & + \\
\hline D-Raffinose & - & - & - & + \\
\hline Amidon & + & - & - & + \\
\hline D-Lyxose & + & - & + & + \\
\hline D-Fucose & + & - & + & + \\
\hline
\end{tabular}

\section{METHODS}

Bacterial strains and cultures. Strain $\mathrm{DJ} 77^{\mathrm{T}}$, S. chlorophenolica DSM 7098 ${ }^{\mathrm{T}}$, S. herbicidovorans DSM $11019^{\mathrm{T}}$ and S. yanoikuyae KCTC $2818^{\mathrm{T}}$ were grown on Trypticase soy agar (TSA; BBL) at $28^{\circ} \mathrm{C}$.

Morphology. The morphological properties were examined after growth on TSA at $28^{\circ} \mathrm{C}$ for $2 \mathrm{~d}$ by light microscopy and scanning electron microscopy (JEOL model JSM-6400).

Determination of physiological characteristics. The oxidation of 95 different carbon sources was tested using BIOLOG GN MicroPlate with an inoculum grown on TSA plates. Oxidation of individual carbon sources was detected indirectly by observing reduction of tetrazolium dye with BIOLOG computer software (GN MicroLog3) after $24 \mathrm{~h}$ incubation at $28{ }^{\circ} \mathrm{C}$. Additional physiological and biochemical traits were determined with API 20NE and 50CHB strips (bioMérieux). The intensity of turbidity was measured after incubation at $28^{\circ} \mathrm{C}$ for 1,2 and $4 \mathrm{~d}$.

Whole-cell fatty acids. In order to analyse fatty acid composition, all of strains were grown on TSA and incubated at $28^{\circ} \mathrm{C}$ for $2 \mathrm{~d}$. Cellular fatty acids of test strains were analysed as methyl esters by GLC according to the instructions of the Microbial Identification System (MIDI).
Respiratory quinones. Cells harvested after culturing for $48 \mathrm{~h}$ at $28^{\circ} \mathrm{C}$ in LB medium were freeze-dried and respiratory quinones were isolated from $100 \mathrm{mg}$ of lyophilized cells according to Collins (1985). Samples were further purified on preparative TLC (Silica Gel $\mathrm{F}_{254}$; Merck) using hexane-diethylether $(85: 15, \mathrm{v} / \mathrm{v})$ as a solvent system. The spots were scraped off and dissolved in chloroform. The samples were analysed by reverse-phase thin-layer partition chromatography using Merck HPTLC RP18F ${ }_{254}$ as described (Collins \& Jones, 1981). Ubiquinone standards were purchased from Sigma and also prepared from $S$. chlorophenolica DSM $7098^{\mathrm{T}}$.

Base composition of DNA. The $\mathrm{G}+\mathrm{C}$ content of the DNA was determined from the mid-point value of the thermal denaturation profile using a spectrophotometer (Ultrospec 2000; Pharmacia Biotech) equipped with a programmable peltier temperature-control unit by the equation of Marmur \& Doty (1962), as modified by De Ley (1970).

DNA-DNA hybridization. DIG-High Prime DNA labelling and Detection Starter Kit II (Boehringer Mannheim) was used for DNA-DNA reassociation experiments. Chromosomal DNAs were prepared following the method of Murray \& Thompson (1980). Duplicate aliquots containing $200 \mathrm{ng}$ of each denatured genomic DNA were transferred onto 
Table 2. Whole-cell fatty acid profile of Pseudomonas sp. DJ77 ${ }^{\top}$ and reference strains

\begin{tabular}{|c|c|c|c|c|c|c|c|c|}
\hline \multirow[t]{2}{*}{ Strain } & \multicolumn{8}{|c|}{ Percentage fatty acid composition $(w / w, \pm 2 \%)^{*}$} \\
\hline & 14:0 2-OH & $\begin{array}{l}\text { Summed } \\
\text { feature } 4\end{array}$ & $16: 0$ & $17: 1 \omega 6 c$ & $\begin{array}{l}\text { Summed } \\
\text { feature } 7\end{array}$ & $16: 1 \omega 5 c$ & $18: 1 \omega 5 c$ & $16: 02-\mathrm{OH}$ \\
\hline Pseudomonas sp. strain $\mathrm{DJ} 77^{\mathrm{T}}$ & 9 & 6 & 12 & 2 & 67 & 1 & 3 & 0 \\
\hline S. yanoikuyae KCTC $2818^{\mathrm{T}}$ & 10 & 13 & 16 & 2 & 52 & 3 & 3 & 1 \\
\hline S. chlorophenolica DSM $7098^{\mathrm{T}}$ & 10 & 8 & 10 & 4 & 62 & 2 & 3 & 1 \\
\hline S. herbicidovorans DSM $11019^{\mathrm{T}}$ & 6 & 9 & 9 & 1 & 68 & 1 & 5 & 1 \\
\hline
\end{tabular}

* Summed features are groups of two or three fatty acids that cannot be separated by GLC with the MIDI system. Summed feature 4 contained one or more of the following fatty acids: $16: 1 \omega 7$ cis and 15:0 iso 2-OH. Summed feature 7 contained one or more of the

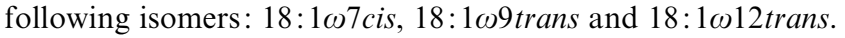

positively charged nylon membrane (Hybond- $\mathrm{N}^{+}$; Amersham) by using a slot blot apparatus (Bio-Rad). The membrane was air-dried and cross-linked. Chromosomal DNAs were denatured by boiling for 10 min and labelled by random priming using DIG-High Prime kit. The membrane was prehybridized in DIG Easy Hyb solution at $68^{\circ} \mathrm{C}$ for $1 \mathrm{~h}$. The labelled probe DNAs were then added to the hybridization solution $(5 \times \mathrm{SSC}, 0 \cdot 1 \% \mathrm{~N}$-lauroylsarcosine, $0.02 \% \mathrm{SDS}, 1 \%$ blocking reagent) and incubated at $68{ }^{\circ} \mathrm{C}$ for $16 \mathrm{~h}$. The resultant membrane was washed to remove nonspecifically bound probe and signals were detected using the DIG chemiluminescent Detection Starter Kit II followed by exposure to X-ray film for periods determined by the sensitivity of the probe. All procedures were performed in accordance with the manufacturer's directions. The signal intensities were measured using a densitometer. The signal produced by self-hybridization of the probe with homologous target DNA was taken as $100 \%$ and each hybridization value was calculated as the mean of three replicates.

16S rDNA analysis. The 16S rDNA was enzymically amplified using two oligonucleotide primers, 27f (AGAGTTTGATCCTGGCTCAG) (Giovannoni, 1991) and 1492r (GGTTACCTTGTTACGACTT) (Lane, 1991). The PCR amplicons were purified by using Wizard Plus SV Minipreps DNA Purification System (Promega) and sequences were determined using Top DNA Sequencing kit and Silverstar Staining kit (BIONEER, Korea). Primers for sequencing are as follows: primer $27 \mathrm{f}$, covering the sequence from positions 8-27 in the 16S rDNA nucleotide sequence of $E$. coli (Brosius et al., 1978); primer Prok4 (TTACCGCGGCTGCTGGCAC; positions 515-535); primer Prok6 (GGGCCCGCACAAGCGG; positions 927-942) and primer 1492r (positions 1477-1492).

The resultant sequence of strain $\mathrm{DJ} 77^{\mathrm{T}}$ was manually aligned with representatives of the genus Sphingomonas and related taxa using known 16S rRNA secondary structure information. Phylogenetic trees were inferred by using the neighbour-joining (Saitou \& Nei, 1987), Fitch-Margoliash (Fitch \& Margoliash, 1967) and maximum-parsimony (Fitch, 1972) methods. Evolutionary distance matrices for the neighbour-joining and Fitch-Margoliash methods were generated according to the model of Jukes \& Cantor (1969). The trees were rooted using Erythrobacter longus (GenBank accession number D12699) and Porphyrobacter neustonensis (M96745) as outgroups. The PHYLIP package (Felsenstein, 1993) was used for all analyses. The resultant tree topology was evaluated in bootstrap analyses (Felsenstein, 1985) of the neighbour-joining method based on 1000 resamplings.

\section{RESULTS}

\section{Morphological properties}

Strain DJ77 ${ }^{\mathrm{T}}$ was Gram-negative, non-motile curved rods, and formed yellow colonies within 2-3 d on halfstrength TSA plates at $28^{\circ} \mathrm{C}$. The colonies were slimy, especially when grown at temperatures below the optimal temperature, i.e. $18^{\circ} \mathrm{C}$. The cell size is $0 \cdot 5-$ $1 \times 1 \cdot 5-3 \mu \mathrm{m}$.

\section{Physiological properties}

Physiological characteristics of strain $\mathrm{DJ} 77^{\mathrm{T}}$ and reference strains are summarized in Table 1. Strain DJ77 ${ }^{\mathrm{T}}$ oxidized about 20 of the 95 different carbon sources tested with the BIOLOG identification system. These results were different from those obtained with $S$. yanoikuyae KCTC $2818^{\mathrm{T}}$, S. chlorophenolica DSM $7098^{\mathrm{T}}$ and $S$. herbicidovorans DSM 11019 ${ }^{\mathrm{T}}$, which were included for the comparative study. The reference strains showed about 31,3 and 18 positive reactions out of the 95 carbon sources, respectively. S. chlorophenolica shows little response towards the majority of the substrates included in the BIOLOG and API identification kits. The substrates oxidized by strain $\mathrm{DJ} 77^{\mathrm{T}}$ in the BIOLOG system were dextrin, glycogen, Tween 40, Tween 80, L-arabinose, $\alpha$-D-glucose, maltose, D-sorbitol, methylpyruvate, formic acid, D-gluconate, $\beta$-hydroxybutyric acid, $\alpha$-keto-butyric acid, DL-lactic acid, alaninamide, L-alanyl-glycine, L-aspartic acid, L-glutamic acid, glycyl-L-glutamic acid and L-proline. Strain $\mathrm{DJ} 77^{\mathrm{T}}$ gave positive results for catalase and oxidase tests and assimilated glucose, L-arabinose, mannose, maltose, gluconate, D-xylose, galactose, D-fructose, aesculin, amidon, D-lyxose and D-fucose in the API test.

\section{Chemotaxonomic characterization}

The whole-cell fatty acid composition of strain $\mathrm{DJ} 77^{\mathrm{T}}$ and related Sphingomonas reference strains are given in Table 2. The dominant fatty acid in strain $\mathrm{DJ} 77^{\mathrm{T}}$ 


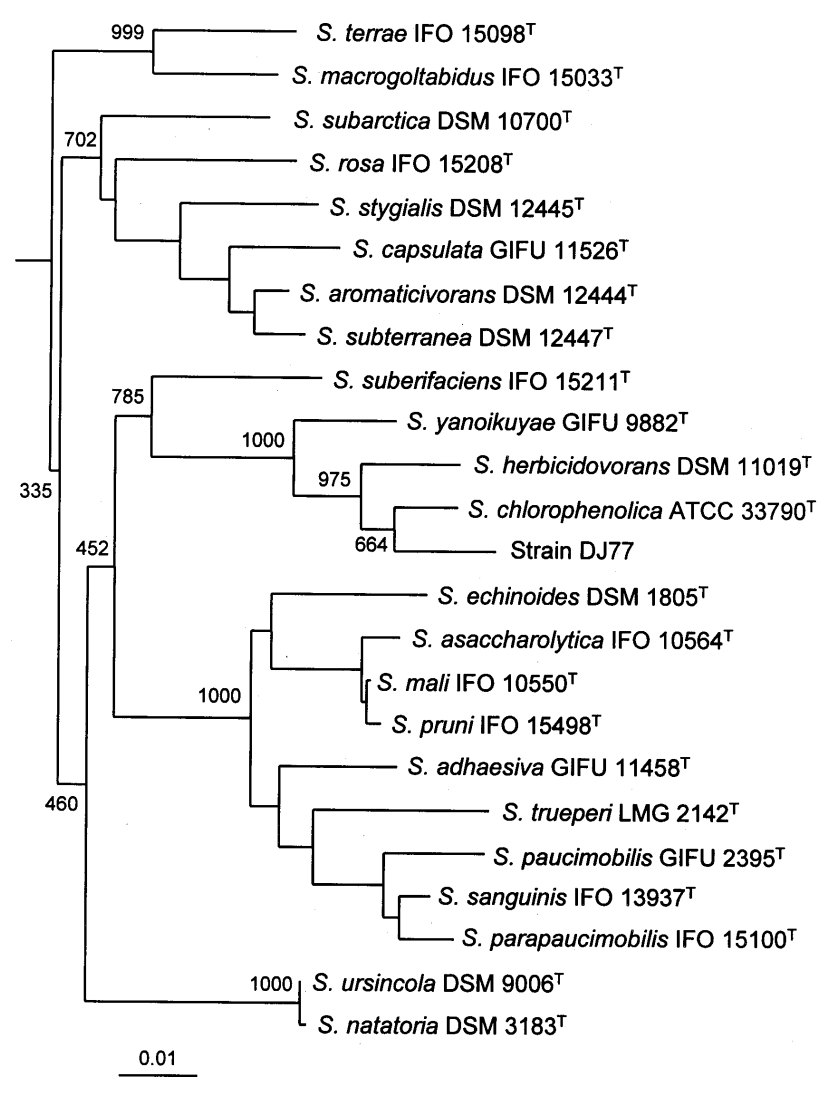

Fig. 1. Rooted neighbour-joining tree based on nearly complete $16 \mathrm{~S}$ rDNA sequences ( 1300 aligned positions) showing relationships between strain $D J 77^{\top}$ and members of the genus Sphingomonas. The numbers at the nodes indicate the levels of bootstrap support based on neighbour-joining analyses of 1000 resampled data sets. The scale bar indicates 0.01 nucleotide substitutions per nucleotide position.

was summed feature $7(18: 1 \omega 7 c, 18: 1 \omega 9 t$ and/or $18: 1 \omega 12 t)$. The other significant fatty acids were 2 hydroxymyristic acid (14:0 2-OH), hexadecanoic acid $(16: 0)$ and summed feature $4(16: 1 \omega 7 c$ and/or $15: 0$ iso 2-OH). Very similar profiles were detected for $S$. chlorophenolica, $S$. herbicidovorans and $S$. yanoikuyae strains. Ubiquinone 10 was the only isoprenologue found in strain $\mathrm{DJ} 77^{\mathrm{T}}$. The ubiquinones of strain $\mathrm{DJ} 77^{\mathrm{T}}$ were identical to those of $S$. chlorophenolica
DSM $7098^{\mathrm{T}}$ and reference ubiquinone 10 purchased from Sigma.

\section{DNA analysis}

A nearly complete $16 \mathrm{~S}$ rRNA sequence of the strain $\mathrm{DJ} 77^{\mathrm{T}}(1435 \mathrm{bp})$ was determined. A preliminary comparison against the GenBank database indicated that the test strain is closely related to the members of the genus Sphingomonas. A rooted phylogenetic tree based on the neighbour-joining method is given in Fig. 1. Strain DJ $77^{\mathrm{T}}$ was recovered in a monophyletic clade containing the type strains of $S$. chlorophenolica, $S$. herbicidovorans and S. yanoikuyae. The relationship was strongly supported by 1000 bootstrap values and by the Fitch-Margoliash and maximum-parsimony treeing algorithms. Sphingomonas suberifaciens was recovered as a sister group to this clade in all of the treeing methods employed in this study. However, it was supported by relatively lower bootstrap value, i.e. 785. The mean 16S rRNA sequence similarity value of strain $\mathrm{DJ} 77^{\mathrm{T}}$ to sphingomonads was $92.8 \pm 1.7 \%$, ranging from $91 \cdot 1$ (Sphingomonas stygialis) to $98 \cdot 1 \%$ (S. chlorophenolica). The type strains of $S$. chlorophenolica, S. herbicidovorans and S. yanoikuyae, which were recovered in a monophyletic clade with strain DJ $77^{\mathrm{T}}$, showed similarity values over $95 \%$ (Table 3 ), and were used for DNA-DNA pairing experiments. The DNA binding values of strain $\mathrm{DJ} 77^{\mathrm{T}}$ to reference sphingomonads ranged from 7 to $14 \%$ (Table 3 ). The $\mathrm{G}+\mathrm{C}$ content of the DNA of strain $\mathrm{DJ} 77^{\mathrm{T}}$ was $63 \mathrm{~mol} \%$.

\section{DISCUSSION}

The genus Sphingomonas was created and subsequently emended by Yabuuchi et al. (1990, 1999) for Gram-negative, strictly aerobic, asporogenous rod- or ovoid-shaped organisms that grow as yellow to whitish brown colonies.

Phylogenetic analysis based on 16S rRNA sequences and chemotaxonomic data clearly indicated that strain DJ $77^{\mathrm{T}}$ belongs to the genus Sphingomonas. Among 23 valid species of the genus Sphingomonas, three species, namely $S$. chlorophenolica, $S$. herbicidovorans and $S$.

Table 3. Phylogenetic relationship of strain $\mathrm{DJ} 77^{\top}$ and related sphingomonads

\begin{tabular}{|c|c|c|c|c|}
\hline & $\begin{array}{l}\text { Strain } \\
\text { DJ77 }\end{array}$ & $\begin{array}{l}\text { S. chlorophenolica } \\
\text { DSM 7098 }\end{array}$ & 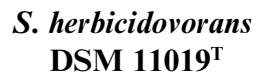 & 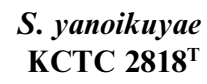 \\
\hline $16 \mathrm{~S}$ rDNA similarity to strain $\mathrm{DJ} 77^{\mathrm{T}}(\%)$ & $100 \cdot 0$ & $98 \cdot 1$ & $96 \cdot 1$ & 95.6 \\
\hline Genomic homology to strain DJ $77^{\mathrm{T}}(\%)^{*}$ & 100 & 13 & 7 & 14 \\
\hline Genomic homology to $S$. chlorophenolica DSM $7098^{\mathrm{T}}(\%) \dagger$ & 10 & 100 & 9 & 10 \\
\hline
\end{tabular}

* Values obtained when DNA of strain DJ77 $77^{\mathrm{T}}$ was labelled.

$\dagger$ Values obtained when DNA of S. chlorophenolica DSM $7098^{\mathrm{T}}$ was labelled. 
yanoikuyae, were found to be closely related in terms of phylogeny. These species and strain $\mathrm{DJ} 77^{\mathrm{T}}$ formed a monophyletic clade and showed very similar cellular fatty acid profiles. However, strain DJ $77^{\mathrm{T}}$ shared very little DNA homology with three Sphingomonas species on the basis of DNA-DNA relatedness experiment. It is evident from the combination of $16 \mathrm{~S}$ rDNA sequencing and DNA-DNA reassociation studies that strain DJ $77^{\mathrm{T}}$ merits a genomic species in the genus Sphingomonas (Stackebrandt \& Goebel, 1994; Wayne et al., 1987). In addition, the organism showed different physiological properties from Sphingomonas species (Table 1).

Old cultures of strain $\mathrm{DJ} 77^{\mathrm{T}}$ became slimy, especially when it was stored at temperatures below room temperature. This feature has been also found in Sphingomonas subarctica (Nohynek, 1996) and is attributed to its ability to produce extracellular polysaccharides. Strain DJ $77^{\mathrm{T}}$ produced extracellular polysaccharides that make the cells attach to one another. Because of the production of this material in excessive amounts, the pellet of strain $\mathrm{DJ} 77^{\mathrm{T}}$ frequently flows away when poured off the medium after centrifugation. This property was not shared by reference strains.

It is noteworthy that among the aromatic-degrading Sphingomonas strains, S. yanoikuyae B1 (Kim, 1996) and Sphingomonas aromaticivorans $\mathrm{F} 199^{\mathrm{T}}$ (Romine et al., 1999) have been studied most extensively at the biochemical and molecular levels. These strains and strain DJ $77^{\mathrm{T}}$ are closely related to each other in genetic backgrounds for aromatic degradation. However, in contrast to $S$. yanoikuyae B1 where the degradative genes were located on the chromosome and $S$. aromaticivorans $\mathrm{F} 199^{\mathrm{T}}$ which originated from deepsubsurface, strain $\mathrm{DJ} 77^{\mathrm{T}}$ has degradative genes on a large plasmid (Kim, 1999) and was originally isolated from sediment.

On the basis of chemotaxonomic and physiological characteristics together with nucleotide sequence analysis of 16S rRNA and DNA-DNA homology studies, we propose that strain $\mathrm{DJ} 77^{\mathrm{T}}$, which was previously identified as Pseudomonas sp., be classified in the genus Sphingomonas as Sphingomonas chungbukensis sp. nov.

\section{Description of Sphingomonas chungbukensis sp. nov.}

Sphingomonas chungbukensis (chung.bu.ken'sis. M.L. adj. chungbukensis named after Chungbuk National University).

Gram-negative, aerobic, mesophilic, asporogenous, curved rods. The cell size is $0 \cdot 5-1 \times 1 \cdot 5-3 \mu \mathrm{m}$. Produces visible, circular, smooth, yellow colonies on TSA in 2-3 d. Oxidase and catalase are positive. Indole, urease, $\beta$-galactosidase and arginine dihydrolase are not produced. Aesculin and gelatin are not hydrolysed. Does not reduce nitrate. Utilizes a variety of aromatic compounds including biphenyl, naphthalene, phen- anthrene, phenol, salicylate, $p$-cresol, $m$-xylene, toluene and benzoate. The following compounds are oxidized: dextrin, glycogen, Tween 40 , Tween 80 , Larabinose, $\alpha$-D-glucose, maltose, D-sorbitol, methylpyruvate, formic acid, D-gluconate, $\beta$-hydroxybutyric acid, $\alpha$-keto-butyric acid, DL-lactic acid, alaninamide, L-alanyl-glycine, L-aspartic acid, L-glutamic acid, glycyl-L-glutamic acid and L-proline. The following compounds are assimilated: glucose, L-arabinose, mannose, maltose, gluconate, D-xylose, galactose, Dfructose, aesculin, amidon, D-lyxose and D-fucose. The major cellular fatty acids are octadecenoic, 2hydroxymyristic, cis-9 hexadecenoic and hexadecanoic acids. The major respiratory quinone is ubiquinone 10 . The $\mathrm{G}+\mathrm{C}$ content of the DNA is $63 \mathrm{~mol} \%$. Sphingomonas chungbukensis is distinct from its phylogenetic neighbours, namely $S$. chlorophenolica, $S$. herbicidovorans and S. yanoikuyae, by low levels of DNA-DNA reassociation, by its ability to produce a great quantity of extracellular polysaccharide and by exhibiting different physiological characteristics. Isolated from chemically contaminated freshwater sediment in Taejon, Republic of Korea. The type strain of the species is DJ $77^{\mathrm{T}}\left(=\mathrm{KCTC} 2955^{\mathrm{T}}=\mathrm{IMSNU} 11152^{\mathrm{T}}\right)$.

\section{ACKNOWLEDGEMENTS}

We thank Hans G. Trüper for the help with nomenclature and Sang-Jin Kim (Korea Ocean Research \& Development Institute) for helpful discussion. This work was supported by grant 1998-015-D00215 of the Korea Research Foundation.

\section{REFERENCES}

Brosius, J., Palmer, J. L., Kennedy, J. P. \& Noller, H. F. (1978). Complete nucleotide sequence of a 16S ribosomal RNA gene from Escherichia coli. Proc Natl Acad Sci USA 75, 4801-4805.

Collins, M. D. (1985). Analysis of isoprenoid quinones. Methods Microbiol 18, 329-366.

Collins, M. D. \& Jones, D. (1981). Distribution of isoprenoid quinone structural types in bacteria and their taxonomic implications. Microbiol Rev 45, 316-354.

De Ley, J. (1970). Re-examination of the association between melting point, buoyant density, and chemical base composition of deoxyribonucleic acid. J Bacteriol 101, 738-754.

Felsenstein, J. (1985). Confidence limits on phylogenies: an approach using the bootstrap. Evolution 39, 783-791.

Felsenstein, J. (1993). PHYLIP (phylogenetic inference package) version 3.5c. Seattle: University of Washington.

Fitch, W. M. (1972). Toward defining the course of evolution: minimum change for a specific tree topology. Syst Zool 20, 406-416.

Fitch, W. M. \& Margoliash, E. (1967). Construction of phylogenetic trees. Science 155, 279-284.

Fredrickson, J. K., Balkwill, D. L., Drake, G. R., Romine, M. F., Ringelberg, D. B. \& White, D. C. (1995). Aromatic-degrading Sphingomonas isolates from the deep subsurface. Appl Environ Microbiol 61, 1917-1922.

Giovannoni, S. (1991). The polymerase chain reaction. In Nucleic Acid Techniques in Bacterial Systematics, pp. 175-201. Edited by E. Stackebrandt \& M. Goodfellow. Chichester: Wiley. 
Hwang, S., Kim, S.-J., Kim, C. K., Kim, Y. \& Kim, Y. C. (1999). The phnIJ genes encoding acetaldehyde dehydrogenase (acylating) and 4-hydroxy-2-oxovalerate aldolase in Pseudomonas sp. DJ77 and their evolutionary implications. Biochem Biophys Res Commun 256, 469-473.

Jukes, T. H. \& Cantor, C. R. (1969). Evolution of protein molecules. In Mammalian Protein Metabolism, vol. 3, pp. 21-132. Edited by H. N. Munro. New York: Academic Press.

Jung, U., Cho, Y. S., Seong, H. M., Kim, S.-J., Kim, Y. C. \& Chung, A.-S. (1996). Characterization of a novel glutathione S-transferase from Pseudomonas sp. DJ77. J Biochem Mol Biol 29, $111-115$.

Ka, J. O., Holben, W. E. \& Tiedje, J. M. (1994). Genetic and phenotypic diversity of 2,4-dichlorophenoxyacetic acid (2,4-D)degrading bacteria isolated from 2,4-D-treated field soils. Appl Environ Microbiol 60, 1106-1115.

Khan, A. A., Wang, R. F., Cao, W. W., Franklin, W. \& Cerniglia, C. E. (1996). Reclassification of a polycyclic aromatic hydrocarbon-metabolizing bacterium, Beijerinckia sp. strain B1, as Sphingomonas yanoikuyae by fatty acid analysis, protein pattern analysis, DNA-DNA hybridization, and $16 \mathrm{~S}$ ribosomal DNA sequencing. Int J Syst Bacteriol 46, 466-469.

Kim, C. K., Kim, J. W., Kim, Y. C. \& Mheen, T. I. (1986). Isolation of aromatic hydrocarbon-degrading bacteria and genetic characterization of their plasmid genes. Kor J Microbiol 24, 67-72.

Kim, E. (1996). Molecular analysis of aromatic hydrocarbon degradation by Sphingomonas yanoikuyae B1. PhD thesis, Rutgers University.

Kim, S. (1999). Genetic analysis of catabolic phn operons for aromatic hydrocarbon degradation by Sphingomonas sp. strain DJ77. PhD thesis, Chungbuk National University.

Kim, S.-J., Kweon, O. K., Kim, Y., Kim, C. K., Lee, K. S. \& Kim, Y. C. (1997a). Localization and sequence analysis of the $p h n H$ gene encoding 2-hydroxypent-2,4-dienoate hydratase in Pseudomonas sp. strain DJ77. Biochem Biophys Res Commun 238, 56-60.

Kim, S.-J., Shin, H.-J., Kim, Y., Kim, S. J. \& Kim, Y. C. (1997b). Nucleotide sequence of the Pseudomonas sp. DJ77 phnG gene encoding 2-hydroxymuconic semialdehyde dehydrogenase. Biochem Biophys Res Commun 240, 41-45.

Kim, S.-J., Shin, H.-J., Park, Y.-C., Kim, Y., Min, K.-H. \& Kim, Y. C. (1999). The 2,3-dihydroxybiphenyl 1,2-dioxygenase gene (phnQ) of Pseudomonas sp. DJ77: nucleotide sequence, enzyme assay and comparison with isofunctional dioxygenases. $J$ Biochem Mol Biol 32, 399-404.

Lane, D. J. (1991). 16S/23S rRNA sequencing. In Nucleic Acid Techniques in Bacterial Systematics, pp. 115-175. Edited by E. Stackebrandt \& M. Goodfellow. Chichester: Wiley.

Marmur, J. \& Doty, P. (1962). Determination of the base composition of deoxyribonucleic acid from its thermal denaturation temperature. J Mol Biol 5, 109-118.
Mueller, J. G., Chapman, P. J., Blattmann, B. O. \& Pritchard, P. H. (1990). Isolation and characterization of a fluoranthene-utilizing strain of Pseudomonas paucimobilis. Appl Environ Microbiol 56, 1079-1086.

Murray, M. G. \& Thompson, W. F. (1980). Rapid isolation of high-molecular-weight plant DNA. Nucleic Acids Res 8, 4321-4325.

Nohynek, L. J., Nurmiaho-Lassila, E.-L., Suhonen, E. L., Busse, H.-J., Mohammadi, M., Hantula, J., Rainey, F. \& Salkinoja-Salonen, M. S. (1996). Description of chlorophenol-degrading Pseudomonas sp. strains KF1T, KF3, and NKF1 as a new species of the genus Sphingomonas, Sphingomonas subarctica sp. nov. Int J Syst Bacteriol 46, 1042-1055.

Romine, M. F., Stillwell, L. C., Wong, K. K., Thurston, S. J., Sisk, E. C., Sensen, C., Gaasterland, T., Fredrickson, J. K. \& Saffer, J. D. (1999). Complete sequence of a 184-kilobase catabolic plasmid from Sphingomonas aromaticivorans F199. J Bacteriol 181, 1585-1602.

Saitou, N. \& Nei, M. (1987). The neighbor-joining method: a new method for reconstructing phylogenetic trees. Mol Biol Evol 4, 406-425.

Shin, H. J., Kim, S.-J. \& Kim, Y. C. (1997). Sequence analysis of the phnD gene encoding 2-hydroxymuconic semialdehyde hydrolase in Pseudomonas sp. strain DJ77. Biochem Biophys Res Commun 232, 288-291.

Stackebrandt, E. \& Goebel, B. M. (1994). Taxonomic note: a place for DNA-DNA reassociation and 16S rRNA sequence analysis in the present species definition in bacteriology. Int $J$ Syst Bacteriol 44, 846-849.

Wayne, L. G., Brenner, D. J., Colwell, R. R. \& 9 other authors (1987). International Committee on Systematic Bacteriology. Report of the ad hoc committee on reconciliation of approaches to bacterial systematics. Int J Syst Bacteriol 37, 463-464.

Wittich, R. M., Wilkes, H., Sinnwell, V., Francke, W. \& Fortnagel, P. (1992). Metabolism of dibenzo-p-dioxin by Sphingomonas sp. strain RW1. Appl Environ Microbiol 58, 1005-1010.

Yabuuchi, E., Yano, I., Oyaizu, H., Hashimoto, Y., Ezaki, T. \& Yamamoto, H. (1990). Proposals of Sphingomonas paucimobilis gen. nov. and comb. nov., Sphingomonas parapaucimobilis sp. nov., Sphingomonas yanoikuyae sp. nov., Sphingomonas adhaesiva sp. nov., Sphingomonas capsulata comb. nov., and two genospecies of the genus Sphingomonas. Microbiol Immunol 34, 99-119.

Yabuuchi, E., Kosako, Y., Naka, T., Suzuki, S. \& Yano, I. (1999). Proposals of Sphingomonas suberifaciens (van Bruggen, Jochimsen and Brown 1990) comb. nov., Sphingomonas natatoria (Sly 1985) comb. nov., Sphingomonas ursincola (Yurkov et al. 1997) comb. nov., and emendation of the genus Sphingomonas. Microbiol Immunol 43, 339-349.

Yrjälä, K., Paulin, L. \& Romantschuk, M. (1997). Novel organization of catechol meta-pathway genes in Sphingomonas sp. HV3 pSKY4 plasmid. FEMS Microbiol Lett 154, 403-408. 